A N N A L E S

UNIVERSITATIS MARIAE CURIE-SKŁODOWSKA

LUBLIN - POLONIA

VOL. LXXIII

SECTIO F

2018

Uniwersytet Rzeszowski

\author{
KINGA FINK \\ ORCID: 0000-0002-6930-8084 \\ kingafink@wp.pl
}

\title{
Lwowscy skrzypkowie pochodzenia żydowskiego w opinii dziennikarzy i krytyków muzycznych w Polsce międzywojennej
}

Music Journalists' and Critics' Views on Lviv Violinists of Jewish Descent in Interwar Poland

\section{STRESZCZENIE}

W międzywojennym Lwowie działało wielu znakomitych skrzypków pochodzenia żydowskiego, którzy aktywnie włączali się w polskie życie muzyczne jako soliści, kameraliści, dyrygenci, członkowie orkiestr oraz pedagodzy. Uczestniczyli nie tylko w życiu koncertowym miasta, występowali bowiem również na polskich i zagranicznych scenach muzycznych i dokonywali nagrań dla Polskiego Radia. Do najwybitniejszych żydowskich skrzypków-wirtuozów związanych ze Lwowem w tym czasie należeli: Robert Perutz, Feliks Eyle i Bronisław Gimpel. Problem sformułowany w tytule niniejszego opracowania dotyczy stosunku krytyków muzycznych (,elit”) do lwowskich muzyków żydowskiego pochodzenia (,obcych”) w okresie międzywojennym, tj. w latach narastania w Polsce antysemityzmu i nacjonalizmu.

Słowa kluczowe: Lwów; II Rzeczpospolita; Żydzi; skrzypkowie; krytyka muzyczna

„Swój” i „obcy” należą do najważniejszych kategorii opisu rzeczywistości społecznej, ponieważ tkwią głęboko w mentalności człowieka, który posługuje się nimi w swojej interpretacji świata. Problematykę opozycji ,swój-obcy” jako jeden z pierwszych podjął w swej rozprawie socjologicznej z 1922 r. Georg Simmel, dla którego prototypem obcego był Żyd w społeczeństwach europejskich, postrzegany jako cudzoziemiec, „osoba bez własnego miejsca”. Na temat wyobcowania Żydów

1 G. Simmel, Obcy, [w:] idem, Socjologia, Warszawa 1975, s. 504-512. Por. E. Nowicka, Swojskość i obcość jako kategorie socjologicznej analizy, [w:] Swoi i obcy, red. E. Nowicka, Warszawa 1990, s. 6. 
w polskim społeczeństwie okresu międzywojennego wypowiadała się Anna Landau-Czajka, współczesna polska badaczka dziejów społeczności żydowskiej w Polsce, podkreślając, że w odniesieniu do Żydów były stosowane inne kryteria niż do pozostałych mniejszości narodowych: „Można było zmieniać narodowości - o ile nie wywodziło się z rodziny żydowskiej. Żydzi pozostawali Żydami na zawsze"².

W okresie międzywojennym Polska należała do państw wyróżniających się wysokim odsetkiem mniejszości narodowych, co było widoczne szczególnie we wschodniej i południowej części kraju, licznie zamieszkanej przez mniejszości słowiańskie i Żydów3 . Pod względem liczby ludności żydowskiej województwo lwowskie ze Lwowem znajdowało się na trzecim miejscu w Polsce; wyprzedzały je jedynie dwa województwa: warszawskie z Warszawą i łódzkie z Łodzią ${ }^{4}$. Duża część społeczności żydowskiej we Lwowie (zwłaszcza liczna w mieście inteligencja) posługiwała się językiem polskim jako językiem ojczystym. Stopień przejmowania polskiego języka i kultury przez mniejszość żydowską był tu zdecydowanie wyższy niż w innych miastach Polski centralnej czy zachodniej ${ }^{5}$. Nigdzie poza Lwowem asymilacja kulturowa nie rozwinęła się na tak szeroką skalę (wpływ miał na to rozwój kultury narodowej, w tym szkolnictwa polskiego w okresie autonomii Galicji) ${ }^{6}$. Trzeba jednak pamiętać, że polonizacja nie zawsze oznaczała pełną asymilację narodową. Przejmowanie elementów kultury polskiej nie było równoznaczne $\mathrm{z}$ utożsamianiem się z narodowością polską. Wśród lwowskiej społeczności żydowskiej posługującej się językiem polskim znajdowali się Żydzi, którzy przyjęli wyznanie rzymskokatolickie (według optyki endeckiej Polaka-katolika przyjęcie chrztu było warunkiem koniecznym do pełnej asymilacji), Żydzi deklarujący bezwyznaniowość, ale też wyznawcy judaizmu, którzy uważali się za „Polaków wyznania mojżeszowego"”.

Żydowskie środowisko muzyczne międzywojennego Lwowa tworzyli zarówno Żydzi postępowi, silnie związani z kulturą polską i lwowską synagogą Tempel, stanowiący elitę lokalnej społeczności żydowskiej, wśród której znajdowali się najwybitniejsi wykonawcy muzyki żydowskiej oraz organizatorzy żydowskiego życia

2 A. Landau-Czajka, Syn będzie Lech... Asymilacja Żydów w Polsce międzywojennej, Warszawa 2006, s. 56.

3 W. Wierzbieniec, Żydzi w województwie lwowskim w okresie międzywojennym. Zagadnienia demograficzne i społeczne, Rzeszów 2003, s. 7.

$4 \quad$ W 1931 r. ludność żydowska w województwie warszawskim z Warszawą liczyła 571783 osób, w województwie łódzkim z Łodzią zamieszkiwało 378495 Żydów, a w województwie lwowskim ze Lwowem - 342 405. Ibidem, s. 32-33.

5 G. Mazur, Życie polityczne polskiego Lwowa 1918-1939, Kraków 2007, s. 78; M.M. Borwicz, Uniwersytet zbirów. Rzecz o Obozie Janowskim we Lwowie 1941-1944, Kraków 2014, s. 178.

6 W. Wierzbieniec, op. cit., s. 34-35.

7 W 1931 r. grupa ta stanowiła 8\% wszystkich mieszkańców Lwowa. Zob. M. Piekarski, Przerwany kontrapunkt. Adolf Chybiński i początki polskiej muzykologii we Lwowie 1912-1944, Warszawa 2017, s. 76. 
muzycznego w mieście ${ }^{8}$, jak i Żydzi ortodoksyjni, tworzący enklawę zamkniętą na bliższe relacje z innymi narodowościami. Natomiast Żydzi pochodzący z rodzin zasymilowanych, którzy pobierali edukację w polskich konserwatoriach muzycznych we Lwowie ${ }^{9}$, aktywnie włączali się w polskie życie muzyczne jako koncertujący artyści (soliści, kameraliści i dyrygenci) oraz kompozytorzy, krytycy muzyczni, pedagodzy i organizatorzy koncertów. Michał Piekarski słusznie podkreślił, że otwartość na przedstawicieli innych narodowości była istotnym czynnikiem rozwoju życia muzycznego Lwowa ${ }^{10}$. Tutejsze kręgi postępowej społeczności żydowskiej promowały narodową kulturę muzyczną, ale jednocześnie sięgały do utworów polskich kompozytorów, włączając je w repertuar swoich imprez z udziałem muzyki ${ }^{11}$. Z kolei polskie instytucje kulturotwórcze nie unikały organizowania koncertów poświęconych muzyce żydowskiej, czego przykładem są występy Izraela Altera (kantora synagogalnego) w sali Polskiego Towarzystwa Muzycznego w 1928 i 1933 r. ${ }^{12} \mathrm{Na}$ tę wyjątkową atmosferę duchową i kulturową Lwowa niewątpliwie wpływ miał nie tylko wyraźnie wieloetniczny charakter miasta, ale także tradycje liberalne Galicji, które - jak twierdzi Hanna Palmon - „dawały [...] muzykom coś unikalnego: wysoki stopień tolerancji i swobody artystycznej”'13.

Problem sformułowany w tytule niniejszego opracowania dotyczy stosunku krytyków muzycznych („elit”) do lwowskich muzyków żydowskiego pochodzenia („obcych”) w okresie międzywojennym, tj. w latach narastania w Polsce antysemityzmu i nacjonalizmu. W wypowiedziach prasowych zainteresowały mnie następujące kwestie: Jak oceniano występy muzyków żydowskich? Czy w recenzjach z koncertów podkreślano ich żydowskie pochodzenie, a jeżeli tak, to w jakim kontekście? Czy kunszt gry muzyków żydowskich był rozpatrywany w kategorii oryginalności wypływającej z etnicznej odmienności? Czy ze strony

8 Na temat życia muzycznego postępowej społeczności żydowskiej we Lwowie zob. S. Jakubczyk-Ślęczka, Żydowskie środowisko muzyczne międzywojennego Lwowa, „Musica Galiciana” 2014, t. 14, s. 245-254.

9 We Lwowie od początku lat 30. XX w., obok Konserwatorium Polskiego Towarzystwa Muzycznego utworzonego przy Galicyjskim Towarzystwie Muzycznym w 1854 r. (oficjalnie zostało zatwierdzone przez Namiestnictwo Galicji w 1880 r.), działały jeszcze dwie placówki o statusie szkoły wyższej. Były to: Lwowskie Konserwatorium Muzyczne im. Karola Szymanowskiego, powstałe na bazie założonego w 1902 r. Lwowskiego Instytutu Muzycznego Anny Niementowskiej, oraz Wyższy Instytut Muzyczny im. Mykoły Łysenki, który powstał w 1903 r. jako pierwsza wieloprofilowa szkoła muzyczna w Galicji z ukraińskim językiem wykładowym. Zob. K. Fink, Szkolnictwo muzyczne we Lwowie w okresie międzywojennym, „Molod' ì rinok. Ŝmìsâčnij naukovo-pedagogičnij žurnal" 2017, nr 4, s. 49.

10 M. Piekarski, op. cit., s. 107.

11 S. Jakubczyk-Ślęczka, op. cit., s. 252, 254.

12 S. Łobaczewska, Z sali koncertowej. J. Alter, „Gazeta Lwowska” 1928, nr 294, s. 5; S. Jakubczyk-Ślęczka, op. cit., s. 246.

13 H. Palmon, Żydowskie środowisko muzyczne Lwowa między wojnami światowymi, www. demusica.pl/cmsimple/images/file/dm13_palmon.pdf [dostęp: 15.09.2017]. 
środowiska muzycznego spotykali się oni z przejawami dyskryminacji na tle różnic wyznaniowych i kulturowych?

Aby udzielić odpowiedzi na wyżej wymienione pytania, przeprowadziłam analizę wypowiedzi dziennikarzy i krytyków muzycznych opublikowanych na łamach prasy międzywojennej (zwłaszcza warszawskiej, lwowskiej, krakowskiej i łódzkiej), odnoszących się wyłącznie do skrzypków pochodzenia żydowskiego działających we Lwowie lub wywodzących się ze Lwowa oraz współtworzących polską kulturę muzyczną, ponieważ skrzypce to „legendarny żydowski instrument klezmerski”, kojarzony z ludową kulturą muzyczną Żydów ${ }^{14}$. Pominęłam wypowiedzi na temat muzyków innych specjalności.

Zachowanym śladem działalności muzyków żydowskich na ziemiach polskich są instrumenty odwzorowane na macewach i dekoracjach synagog, wśród których niejednokrotnie umieszczano skrzypce ${ }^{15}$. Typowym dla kapel klezmerskich, działających w wielu małych miasteczkach i wsiach w Polsce pod koniec XVIII w., instrumentarium były cymbały i skrzypce (pojawiły się w gettach niemieckich już pod koniec XVII w.), ale również kontrabas, a później klarnet (w połowie XIX w.) należały do wyposażenia wielu takich zespołów ${ }^{16}$. Jeszcze w XIX w. w Polsce widok „wędrującego handlarza, dźwigającego obok worka z towarem także cymbały lub skrzypce, nie należał [...] do rzadkości"' ${ }^{17}$. Według przekazów matki genialnego skrzypka Yehudi Menuhina wśród Żydów emigrujących masowo z Rosji do Stanów Zjednoczonych po 1880 r. ${ }^{18}$ trudno „było spotkać bodaj jednego bez futerału na skrzypce" ${ }^{19}$. Skrzypce, jak twierdził Menuhin, stały się ulubionym instrumentem dwóch narodów tułaczy: Żydów i Cyganów. Zarówno pierwsi, jak i drudzy w swych wędrówkach traktowali je jak łatwego do przenoszenia towarzysza, którego głos był zdolny wyśpiewać ich zachwyt i smutki ${ }^{20}$.

14 Cyt. za: M. Fuks, Muzyka ocalona. Judaica polskie, Warszawa 1989, s. 30. Klezmer, według definicji Mosze Beregowskiego, to żydowski profesjonalny muzyk-instrumentalista ludowy. Zob. S. Jakubczyk, Klezmerskiej muzyki próba zrozumienia retrospektywna, „Kwartalnik Młodych Muzykologów UJ" 2008, nr 2, s. 11.

15 Zob. B. Vogel, „Na wierzbach zawiesiliśmy nasze... skrzypce”. Rzecz o dawnych instrumentach, macewach, synagogach i klezmerach, „Muzyka” 2007, nr 2, s. 75-101.

16 Ibidem, s. 93, 95-96; S. Jakubczyk, op. cit., s. 17; P. Dahlig, O Jankiel - historia, poezja i codzienność, „Muzykalia” 2012, z. 13/Judaica 4, s. 4.

17 Cyt. za: M. Fuks, Tradycje muzyczne polskich Żydów, [w:] Studia z dziejów Żydów w Polsce. Materiały edukacyjne dla szkót średnich $i$ wyższych, red. E. Lewczuk, t. 2, Warszawa 1995, s. 124.

18 Masowe migracje Żydów rosyjskich do Stanów Zjednoczonych odbywały się na skutek fali antysemickich pogromów w Imperium Rosyjskim, które miały miejsce w latach 1881-1884 i 1903-1906.

19 Cyt. za: Y. Menuhin, Skrzypce i ja, przy współudziale C. Meyer, Warszawa 2000, s. 121.

20 Ibidem, s. 119, 143, 283. O szczególnym zamiłowaniu Żydów do skrzypiec wypowiadała się także Ida Haendel: „Humorystycznie mówi się, że ponieważ Żyd był tułaczem, to nie mógł za sobą ciągnąc fortepianu i stąd te skrzypce. Ale teraz to się zmieniło. Jest wielu znakomitych skrzypków, którzy nie są Żydami. Nie jestem tak zarozumiała, żeby twierdzić, że tylko Żydzi dobrze grają”. Zob. 
Przeważnie skrzypkowie z kapel klezmerskich nie znali nut, a ich instrumenty były dziełami ludowych lutników. Ich kunszt gry podglądali wykształceni wirtuozi, pragnący zgłębić tajemnicę techniki smyczkowania i różnorodnych efektów artykulacyjnych ${ }^{21}$. Charakterystyczny dla żydowskich skrzypków sposób wydobycia i kształtowania dźwięku na instrumencie pamiętali jeszcze w latach 50. XX w. niektórzy przedstawiciele najstarszego pokolenia ludowych muzyków na Lubelszczyźnie, używający specyficznych określeń wykonawczych, jak np. „granie po żydowsku” czy „graj tak, aby twoje skrzypce płakały”22.

Zapoczątkowany w drugiej połowie XIX w. i kontynuowany w pierwszych dekadach XX w. kult wirtuozów objął całą plejadę doskonałych skrzypków pochodzenia żydowskiego, urodzonych głównie w Europie Środkowej i Wschodniej, a zwłaszcza w Rosji, wykształconych w najlepszych konserwatoriach w Wiedniu, Berlinie, Petersburgu czy Moskwie. Najwybitniejsi mistrzowie w dziejach światowej wiolonistyki mogą być niejako potwierdzeniem panującego od lat przekonania, że Żydzi mają szczególne predyspozycje do skrzypiec $^{23}$. Wymienię tylko niektórych: Joseph Joachim (1831-1907), Fritz Kreisler (1875-1962), Jascha Heifetz (1901-1987), Dawid Ojstrach (1908-1974), Yehudi Menuhin (1916-1999), Isaak Stern (1920-2001), Itzhak Perlman (ur. 1945), Shlomo Minz (ur. 1957), Joshua Bell (ur. 1967). Są wśród nich także nasze rodzime chluby: Henryk Wieniawski24 (1835-1880), Bronisław Huberman

„Znak od Boga”. Z Idą Haendel, światowej sławy skrzypaczka, jurorem XIII Konkursu Skrzypcowego im. H. Wieniawskiego, rozmawia Agnieszka Lewandowska, „Twoja Muza” 2007, nr 1.

${ }_{21}$ Muzyka klezmerska swoje charakterystyczne brzmienie zawdzięcza wpływowi żydowskiej muzyki wokalnej, co szczególnie słychać w grze skrzypków i klarnecistów stosujących różnego rodzaju ozdobniki dla wywołania np. lamentu, jęku, westchnienia, gwizdu czy śmiechu. Na grze znanego w praskim świecie klezmerskim ,ślepego Lejbla” wzorował się Franciszek Benda (17091786) - znakomity czeski skrzypek, który dla doskonalenia swojej techniki skrzypcowej podróżował z kapelą po Czechach i Morawach. Zob. S. Jakubczyk, op. cit., s. 12, 17. Por. M. Fuks, Tradycje muzyczne..., s. 125.

22 Potwierdzają to badania etnomuzykologiczne Anny Czekanowskiej (zob. Muzyka żydowska - modlitwa i pieśń, [w:] eadem, Kultury tradycyjne wobec wspótczesności. Muzyka, poezja, taniec, Warszawa 2008, s. 215, 223, przypis 89). Etnograf Franciszek Kotula (1900-1983) upamiętnił w swych wspomnieniach żydowskie małżeństwo Szwarców z Rzeszowszczyzny. Ci ludowi muzycy zarabiali grą w karczmie lub na weselach. Podziw wzbudzała zwłaszcza Żydówka grająca na skrzypcach. Zob. F. Kotula, Muzykanty, Warszawa 1979, s. 42-43.

${ }_{23}$ M. Fuks, Muzyka ocalona ..., s. 108; idem, Wielcy i sławni pochodzenia żydowskiego, Łódź 1998, s. 90.

${ }^{24}$ Na podstawie badań źródłowych przeprowadzonych przez Ludwika Gawrońskiego z całą pewnością wiadomo, że ród Wieniawskich zawdzięcza swoje nazwisko podlubelskiej Wieniawie. Ojciec Henryka Wieniawskiego - Wolf Helman - urodził się w rodzinie żydowskiego cyrulika Herszka Mayera Helmana i Gitli Aronowicz. Świadectwo maturalne otrzymał jako Tobiasz Wieniawski, a studia ukończył jako Tadeusz Tobiasz Wieniawski. W 1823 r. otrzymał stopień magistra filozofii, w 1825 r. - magistra medycyny, a w 1828 r. - akademicki stopień magistra chirurgii. W tym samym roku został ochrzczony. Matką Henryka Wieniawskiego była Regina Wolff - córka 
(1882-1947), Paweł Kochański (1887-1934), Ida Haendel (ur. 1928) i Wanda Wiłkomirska (1929-2018).

W międzywojennym Lwowie działało wielu znakomitych skrzypków pochodzących ze zasymilowanych rodzin żydowskich, którzy jako soliści, kameraliści i członkowie orkiestr uczestniczyli w życiu koncertowym miasta, występowali na polskich i zagranicznych scenach muzycznych oraz dokonywali nagrań dla Polskiego Radia. Do grona najwybitniejszych skrzypków-wirtuozów związanych ze Lwowem należeli: Robert Perutz, Feliks Eyle i Bronisław Gimpel. Odnieśli oni międzynarodowe sukcesy. Wielu lwowskich skrzypków narodowości żydowskiej uprawiało muzykę kameralną. W Kwartecie Smyczkowym Polskiego Towarzystwa Muzycznego grali: Marek Bauer, Leon Sak (Sack, Zak) i Marek Rak; w skład tria Polskiego Towarzystwa Muzycznego wchodzili: Stanisław (Samuel) Krebs i Jakub Mund, który równocześnie występował w Kwartecie Smyczkowego Międzynarodowego Towarzystwa Muzyki Współczesnej we Lwowie ${ }^{25}$. Funkcję koncertmistrzów orkiestry Opery Lwowskiej, a następnie Teatru Wielkiego we Lwowie, pełnili kolejno: Maurycy Wolfsthal (od 1889 r.), Rudolf Deman (właśc. Diamant, w latach 1901-1908), a w okresie międzywojennym - Franciszek Józef Horowitz i Marek Rak oraz Emma Wolfsthal (od 1920 r.) jako drugi koncertmistrz orkiestry ${ }^{26}$. W orkiestrze Filharmonii Lwowskiej grali Marek Rak oraz Jakub Mund (koncertmistrz) i Marceli Horowitz, którzy okresowo byli też jej dyrygentami ${ }^{27}$, a w orkiestrze symfonicznej Polskiego Towarzystwa Muzycznego we Lwowie - Kazimierz Halpon (koncertmistrz), Eugeniusz Landowski i skrzypekamator Maurycy Diamand ${ }^{28}$. Ponadto orkiestry jazzowe i zespoły instrumentalne, grające w kawiarniach, restauracjach i lokalach rozrywkowych we Lwowie, miały wśród swoich członków znakomitych skrzypków o żydowskich korzeniach. Byli to: Eugeniusz Landowski, Zygmunt Fajerberg, Zygmunt Schatz (dyrygował orkiestrą w słynnej kawiarni Hotelu George) oraz Leopold Strick (członek orkiestry Karola Austerlitza, kompozytor muzyki do pierwszego polskiego filmu anonimowego zrealizowanego we Lwowie w 1931 r. przez Jana Jarosza) $)^{29}$.

Skrzypkowie pochodzenia żydowskiego byli aktywni także na polu pedagogicznym, podejmowali bowiem zatrudnienie w szkolnictwie muzycznym we

warszawskiego lekarza Józefa Wolffa, która została ochrzczona zaledwie dzień przed ceremonią zaślubin. Zob. L. Gawroński, Saga rodu Wieniawskich, Lublin 2003, s. 9-10, 15, 53.

25 L.T. Błaszczyk, Żydzi w kulturze muzycznej ziem polskich w XIX i XX wieku. Słownik biograficzny, Warszawa 2014, s. 60, 143, 148-149, 181, 204, 217.

26 A. Plohn, Muzyka we Lwowie a Żydzi, „Muzykalia” 2012, z. 13/Judaica 4, s. 8 (pierwotna publikacja: „Almanach Żydowski” 1936, nr 8); L.T. Błaszczyk, op. cit., s. 54, 113, 204, 283-284.

27 L.T. Błaszczyk, op. cit., s. 113, 181, 204; J.J. Dunicz, Z ruchu muzycznego w Polsce. Lwów, „Muzyka Polska” 1936, z. 2, s. 134; idem, Z ruchu muzycznego..., „Muzyka Polska” 1937, z. 5, s. 250 .

28 L.T. Błaszczyk, op. cit., s. 55, 102, 152.

29 Ibidem, s. 64, 152, 219, 235. 
Lwowie, a w niektórych przypadkach również w Wiedniu lub innych ważnych ośrodkach muzycznych w Europie. Długoletnim profesorem Konserwatorium Polskiego Towarzystwa Muzycznego (przed 1919 r. - Galicyjskiego Towarzystwa Muzycznego) był Maurycy Wolfsthal, wywodzący się ze znanej we Lwowie rodziny muzyków. To postać niezwykle zasłużona dla rozwoju życia muzycznego miasta $^{30}$. W ciągu swej 54-letniej działalności dydaktycznej (w latach 1883-1937) wychował grono znakomitych skrzypków, podziwianych na wielu estradach w kraju i na świecie. W okresie międzywojennym w Konserwatorium Polskiego Towarzystwa Muzycznego pracowała też jego córka, skrzypaczka Emma Wolfsthal, oraz wielu innych skrzypków o żydowskich korzeniach, m.in. Marek Bauer, Juliusz Weber (późniejszy profesor Akademii Muzycznej w Krakowie, nauczyciel skrzypiec Zbigniewa Wodeckiego w krakowskiej Państwowej Szkole Muzycznej II stopnia im. Władysława Żeleńskiego) ${ }^{31}$. W Lwowskim Instytucie Muzycznym Anny Niementowskiej, który w latach 30. zmienił status na Konserwatorium Muzyczne im. Karola Szymanowskiego, klasę skrzypiec prowadzili: Robert Perutz, Bronisław Gimpel, Marek Bauer, Jakub Mund, Dawid Deutsch, Eisig Cymbalist, Juliusz Sperber i Stanisław (Samuel) Krebs ${ }^{32}$. Duża grupa muzyków pochodzenia żydowskiego była zatrudniona w Szkole Muzycznej im. Ignacego J. Paderewskiego. Pracowali tu m.in. skrzypkowie Kazimierz Halpon i Fryderyk Lilienthal, który prowadził też klasę skrzypiec w Szkole Muzycznej Sabiny Kasparek we Lwowie ${ }^{33}$. Z kolei Marek Rak i Leon Sak nauczali w Prywatnym Lwowskim Instytucie Muzycznym kierowanym przez Romana Fiszlera, a Maurycy Horowitz - w zarządzanej przez Rebekę Sigal-Katz Szkole Muzycznej im. Fryderyka Chopina, gdzie prowadził klasę skrzypiec i kameralistyki oraz chór i orkiestrę ${ }^{34}$. Cenioną we Lwowie prywatną placówką edukacyjną była działająca przez 27 lat Szkoła Gry na Skrzypcach Maksymiliana Markusa, kierowana w drugiej połowie lat 30. przez jego córkę, Idę Gang1 ${ }^{35}$. Znaczna część żydowskich artystów współtworzących polską kulturę muzyczną utrzymywała łączność z żydowskim środowiskiem muzycznym we Lwowie, angażując się w działalność m.in. Teatru Żydowskiego (kierowanego przez rodzinę Gimplów) i Żydowskie-

30 Ibidem, s. 282, 284.

31 J.J. Dunicz, Z ruchu muzycznego w Polsce. Lwów, „Muzyka Polska” 1937, z. 1, s. 35-36; Koncerty. Uczniowski koncert Konserwatorium P.T.M., „Echo. Miesięcznik poświęcony kulturze muzycznej Lwowa” 1936, nr 2, s. 11; L. Mazepa, T. Mazepa, Šláh do Muzičnoi Akademii u L’vovi, t. 1, L'viv 2003, s. 189.

32 „Słowo Polskie” 1922, nr 207, s. 4; L. Mazepa, T. Mazepa, op. cit., s. 210; L.T. Błaszczyk, op. cit., s. 26, 50, 55, 81, 143, 181, 230.

33 „Gazeta Lwowska” 1932, nr 226, s. 5; L.T. Błaszczyk, op. cit., s. 102, 161, 242.

34 L.T. Błaszczyk, op. cit., s. 113, 204, 217.

35 A. Plohn, op. cit., s. 17; L. Mazepa, T. Mazepa, op. cit., s. 121; L.T. Błaszczyk, op. cit., s. 78,170 . 
go Towarzystwa Muzycznego ${ }^{36}$. Na licznie organizowanych przez Towarzystwo koncertach jako soliści i kameraliści występowali m.in. Bronisław Gimpel, Leon Striks, Zygmunt Schatz, Marceli Horowitz, Leon Sak, Fryderyk Herman i Michał Sokaler, a dyrygentami orkiestry symfonicznej Towarzystwa byli kolejno skrzypkowie: Natan Hermelin, Juliusz Weinberger i Marceli Horowitz ${ }^{37}$.

$\mathrm{Na}$ łamach prasy międzywojennej stale obecne były nazwiska Roberta Perutza, Feliksa Eyle’a i Bronisława Gimpla, którzy karierę muzyczną rozpoczęli w rodzinnym Lwowie, a uznanie jako skrzypkowie-wirtuozi zdobyli za granicą. Robert Perutz ${ }^{38}$ (1886-1934) w grze skrzypcowej kształcił się u Maurycego Wolfsthala we Lwowie, Henriego Marteau w Genewie oraz Carla Flescha w Berlinie. W latach 1910-1912 był profesorem Konserwatorium w Valparaiso w Chile, a po powrocie do Lwowa od 1913 r. do wybuchu wojny - Konserwatorium Galicyjskiego Towarzystwa Muzycznego. W latach 1919-1920 prowadził klase fortepianu w Wyższym Instytucie Anny Niementowskiej, a następnie osiedlił się w Stanach Zjednoczonych, gdzie wykładał w Konserwatorium Muzycznym w Cincinnati i odbywał podróże koncertowe po Stanach Zjednoczonych (m.in. z Perutz String Quartet). Po opuszczeniu kraju utrzymywał relacje z Polską m.in. jako felietonista i korespondent muzyczny wielu polskich czasopism ${ }^{39}$. W $1919 \mathrm{r}$., przed wyjazdem do Ameryki, dał serię koncertów w różnych miastach Polski: Lwowie, Łodzi, Lublinie, Kaliszu, Częstochowie, Sosnowcu, Rzeszowie, Tarnowie, Zakopanem, Nowym Sączu, Bochni, Sanoku, Jarosławiu ${ }^{40}$. Repertuar jego koncertów obejmował zarówno rozbudowane dzieła symfoniczne z rolą koncertującą fortepianu (m.in. Koncert skrzypcowy A-dur op. 8 Mieczysława Karłowicza), jak i drobne wirtuozowskie dzieła skrzypcowe Bacha, Paganiniego, Kreislera, Młynarskiego, Różyckiego i innych kompozytorów.

Opinie prasowe z koncertów Perutza były utrzymane w pochlebnym tonie. Przez wywodzącego się ze Lwowa recenzenta muzycznego Karola Stromengera został określony mianem „muzyka inteligentnego i wielostronnego" ${ }^{4}$. Podobnie

36 Żydowskie Towarzystwo Muzyczne na skutek problemów finansowych przestało istnieć jako samodzielna organizacja w 1926 r. i od tego czasu formalnie działało jako sekcja muzyczna Żydowskiego Towarzystwa Artystyczno-Literackiego. Zob. S. Jakubczyk-Ślęczka, op. cit., s. 252.

37 Ibidem, s. 250-253. Por. L.T. Błaszczyk, op. cit., s. 106-107, 113, 228, 271, 296.

38 Kronika, „Gazeta Narodowa” 1898, nr 191, s. 3; S. Niewiadomski, Przeglad muzyczny, „Słowo Polskie” 1904, nr 559, s. 5; E. Walter, Z muzyki. (Koncert Roberta Perutza), „Gazeta Lwowska” 1913, nr 87, s. 4; Wiadomości z kraju i z zagranicy, „Gazeta Muzyczna” 1919, nr 24, s. 177; K.[arol] S.[tromenger], Robert Perutz. (Wspomnienie pośmiertne), „Gazeta Polska” 1934, nr 86, s. 4; L.T. Błaszczyk, op. cit., s. 194-195.

39 Zob. R. Perutz, Wrażenia z Koncertu Paderewskiego w Ameryce, „Muzyka” 1931, nr 3, s. $132-136$.

40 Wiadomości z kraju i z zagranicy, „Gazeta Muzyczna” 1919, nr 11, s. 86; Koncert skrzypka wirtuoza, „Goniec Częstochowski” 1919, nr 43, s. 3.

41 K. Stromenger, Przegląd muzyczny, „Tygodnik Ilustrowany” 1927, nr 39, s. 798. 
o jego grze wypowiadał się pianista Franciszek Neuhauser. Piszący dla „Gazety Lwowskiej” Neuhauser, oprócz uwypuklenia walorów jego interpretacji (,,pięknie prowadzona kantylena” oraz „błyskotliwe flażolety”), podkreślał umiejętny dobór utworów programu koncertu tego skrzypka, dzięki czemu ,znalazł [...] aż nadto sposobności do wykazania licznych intelektualnych bądź technicznych zalet swej gry wirtuozowskiej”, w której najwyższe trudności były pokonywane „Z niezachwianym spokojem”42. Kompozytor Stanisław Niewiadomski, prowadzący również ożywioną działalność publicystyczną, uważał wprawdzie technikę gry Perutza za „bardzo biegłą, prawdziwie wirtuozowską" i „pełną elegancji”, ale jednocześnie za ,nieco nerwową"43.

Feliks Eyle ${ }^{44}$ (1899-1988), uczeń Wacława Kochańskiego we Lwowie, kształcił się u Arnolda Roségo w Wiedniu i Jenö Hubaya w Budapeszcie. W latach 20. uczył gry na skrzypcach w Instytucie Muzycznym w Krakowie oraz prowadził działalność koncertową w Polsce i za granicą jako solista i kameralista. W 1928 r. wyemigrował do Stanów Zjednoczonych. Początkowo grał w Cleveland Symphony Orchestra i pełnił funkcję zastępcy koncertmistrza oraz wykładał w Cleveland Music School Settlement. Następnie w latach 1945-1971 był koncertmistrzem orkiestry Metropolitan Opera w Nowym Jorku, a od 1957 r. - jej menedżerem. Ponadto był pedagogiem w Colgate University w Hamilton. Na łamach polskich gazet ukazały się m.in. recenzje z jego koncertów we Lwowie i Krakowie z 1922 r. oraz w Łodzi z 1924 r. W programie jego koncertów znajdowały się większe formy wykonywane $\mathrm{z}$ orkiestrą (m.in. Koncert skrzypcowy D-dur op. 77 Johannesa Brahmsa i Koncert skrzypcowy e-moll op. 64 Felixa Mendelssohna) lub z fortepianem (m.in. Sonata g-moll Giuseppe Tartiniego), a także drobne utwory kameralne (m.in. Rimskiego-Korsakowa i Szymanowskiego). Recenzje z koncertów Eyle'a we Lwowie i Krakowie w listopadzie 1922 r. ukazały się na łamach lokalnych dzienników żydowskich. Alfred Jendl, jeden z najbardziej liczących się dziennikarzy muzycznych Krakowa, określił 22-letniego skrzypka mianem ,wschodzącej gwiazdy na firmamencie skrzypcowej sztuki”45. Dokonując, przy użyciu licznych metafor, wysokiej oceny techniki gry młodego wirtuoza, która w jego opinii szła w parze z siłą wyrazu jego interpretacji, wróżył mu „duże powodzenie artystyczne w przyszłości”" ${ }^{\text {* }}$. Nieco bardziej sceptyczny w pochwałach był Alfred Plohn, sprawozdawca muzyczny lwowskiej „Chwili”, który uznając ,niepowszedni talent” młodego skrzypka, jednocześnie dostrzegał w jego grze pewne niedociągnięcia techniczne i nie

42 F. Neuhauser, $Z$ muzyki, „Gazeta Lwowska” 1919, nr 134, s. 6.

43 st.[anisław] n.[iewiadomski], Z sali koncertowej, „Gazeta Muzyczna” 1919, nr 19/20, s. 144.

44 Rozmaitości, „Muzyk Wojskowy” 1928, nr 23, s. 9; L.T. Błaszczyk, op. cit., s. 63.

45 Alf.[red] Jen.[dl], Z muzycznej estrady $i$ sceny, „Wiadomości Krakowskie” 1922, nr 41, s. 4.

46 Ibidem. 
całkiem jeszcze wykształconą umiejętność wyczucia stylu wykonywanych kompozycji, zwłaszcza cyklicznych ${ }^{47}$. Jeszcze bardziej krytyczny wobec występu Eyle'a był Adam Mitscha, wychowanek lwowskiej szkoły muzykologicznej, profesor Konserwatorium Polskiego Towarzystwa Muzycznego, recenzent muzyczny „Słowa Polskiego”. Dla Mitschy Eyle reprezentował typ wirtuoza popisującego się przede wszystkim „ekwilibrystyką techniczną, mniej zaś pięknością tonu i czynnikiem duchowym"48. Mimo zarzutów wobec artysty, które koncentrowały się wokół braku zachowania należytych proporcji, Mitscha podzielał opinie innych krytyków i pisał: „,...] spostrzeżenia nie negują w niczym kariery wirtuozowskiej”, dodając, że Eyle „ma przed sobą piękną przyszłość”49. W 1924 r. podczas koncertu w Łodzi gra Eyle’a odznaczała się już większą dojrzałością i zachowaniem właściwej równowagi, przez dziennikarza „Głosu Polskiego” został bowiem doceniony za „niewielki, ale zmysłowy” dźwięk, technikę „uporządkowaną bardzo starannie” i „szlachetność stylu” "50.

Wywodzący się ze słynnej lwowskiej rodziny muzyków Bronisław Gimpel ${ }^{51}$ (1911-1979) należał do wirtuozów, którzy swoją grą zadziwiali świat. Po studiach w Konserwatorium Polskiego Towarzystwa Muzycznego u Maurycego Wolfsthala kształcił się w grze skrzypcowej w Wiedniu i Berlinie kolejno u Roberta Pollaka, Carla Flescha i Bronisława Hubermana. Na lwowskiej scenie muzycznej Gimpel zadebiutował w wieku ośmiu lat, a światową karierę rozpoczął w 1925 r. koncertem w Wiedniu. Rok później odbył tournée koncertowe po Włoszech, gdzie wystąpił m.in. przed papieżem Piusem XI, królem Wiktorem Emanuelem III i nad grobem Paganiniego w Genui - tu dostąpił zaszczytu grania na jego legendarnych skrzypcach wykonanych przez Guarneriego del Gesú. W ciągu kolejnych kilku lat wystapił w wielu krajach Europy oraz Ameryki Północnej i Południowej. W latach 30. był koncertmistrzem orkiestry w Królewcu, a później - w Göteborgu. W 1935 r. został laureatem VII nagrody Międzynarodowego Konkursu Skrzypcowego im. Henryka Wieniawskiego w Warszawie, a dwa lata później wyemigrował do Stanów Zjednoczonych. Po wojnie występował na całym świecie, w tym w Polsce; często grał z pianistą Władysławem Szpilmanem, z którym wspólnie założyli w 1962 r. Warszawski Kwintet Smyczkowy. Gimpel, podobnie jak Perutz

47 A. Plohn, Z sali koncertowej. Feliks Eyle, „Chwila” 1922, nr 1337, s. 3.

48 A. Mitscha, Z sali koncertowej. Feliks Eyle, , Słowo Polskie” 1922, nr 5, s. 2.

49 Ibidem.

50 F.R. Hal, Teatr i muzyka, „Głos Polski. Dziennik polityczny, społeczny i literacki” 1924, nr 17, s. 4.

51 J. Weber, Gimpel Bronisław, [w:] Encyklopedia muzyczna PWM. Część biograficzna, red. E. Dziębowska, t. 3, Kraków 1987, s. 308-309 (autor opracowania pominął kwestię żydowskiego pochodzenia skrzypka); M. Fuks, Muzyka ocalona..., s. 218-220; I. Fater, Bronistaw Gimpel (1911-1979), [w:] idem, Muzyka żydowska w Polsce w okresie międzywojennym, Warszawa 1997, s. 98-103; L.T. Błaszczyk, op. cit., s. 81. 
i Eyle, przyczynił się do popularyzacji muzyki polskiej na świecie. Był niedoścignionym mistrzem w interpretacjach utworów Wieniawskiego ${ }^{52}$. Współcześnie zaliczany jest do najwybitniejszych wirtuozów XX w.

W latach 1928-1935 Gimpel wystąpił m.in. w takich polskich ośrodkach, jak: Warszawa, Lwów, Łódź, Kraków, Katowice, Przemyśl, Zakopane ${ }^{53}$. Programy jego koncertów były ułożone w sposób przekrojowy - obejmowały muzykę od XVII do XX w. Składały się z utworów skrzypcowych z towarzyszeniem orkiestry, dzieł kameralnych oraz utworów na skrzypce solo (m.in. Bacha, Corellego, Tartiniego, Paganiniego, Mendelssohna, Debussy'ego, Bartoka), w tym inspirowanych folklorem żydowskim kompozycji Brucha i Achrona. Po koncertach w Warszawie w 1928 r. wymagający krytyk, jakim był Felicjan Szopski, określił grę młodego, wówczas 17-letniego wirtuoza jako połączenie doskonałej techniki z umiejętnością operowania niedużym, ale „bardzo wdzięcznym” dźwiękiem oraz „wybitną muzykalnością" ${ }^{54}$. Inny dziennikarz muzyczny, Leopold Binental, zaliczył Gimpla do „szlachetnego gatunku wirtuozów” - do wirtuozów-poetów, którego gra nie jest nastawiona wyłącznie na efekt, lecz odznacza się „,szczerością odczucia, nastrojonego na górny poetycki ton" 55 . Po upływie dwóch lat, w trakcie których studiował u Carla Flescha w Berlinie, Gimpel ponownie wystąpił w Warszawie. Ten sam recenzent zarzucił mu nadmierną czułostkowość, dominującą nad właściwym sposobem odczytania przynależnych konwencji stylistycznych wykonywanych utworów ${ }^{56}$. Duży sceptycyzm Binentala wzbudził kolejny występ wirtuoza w Warszawie w 1931 r. Krytyk, z uwagą śledzący rozwój indywidualności artystycznej Gimpla, wytknął mu brak równowagi między właściwym zrozumieniem a wyrazem oraz stylistyczno-muzycznymi aspektami skrzypcowej interpretacji, ponadto dostrzegł zbytnią brawurę i zalecił lepsze panowanie nad emocjami i szczegółami interpretacyjnymi ${ }^{57}$. Binental, który zasiadał w jury I Międzynarodowego Konkursu Skrzypcowego im. Henryka Wieniawskiego w 1935 r., w prasowej relacji z konkursu scharakteryzował Gimpla w lapidarnym opisie - wyróż-

52 A. Cofalik, Ukochatem skrzypce. Ze wspomnień skrzypka i pedagoga, Kraków 2016, s. 69.

53 „Ilustrowana Republika” 1928, nr 39, s. 8, nr 40, s. 6; „Nowy Dziennik” 1928, nr 13, s. 4, nr 350, s. 11; „Nasz Przegląd” 1928, nr 288, s. 13; „Kurier Warszawski” 1928, nr 27 (wydanie wieczorne), s. 5, nr 291 (wydanie wieczorne), s. 10; „Kurier Warszawski” 1930, nr 281 (wydanie wieczorne), s. 8; „Kurier Warszawski” 1931, nr 7 (wydanie wieczorne), s. 7; „Gazeta Lwowska” 1929, nr 1, s. 6; „Zakopane” 1930, nr 30, s. 8, nr 31, s. 7; „Nowy Dziennik” 1932, nr 257, s. 14, nr 266, s. 12; „Polska Zachodnia” 1935, nr 5, s. 9, nr 6, s. 11, nr 12, s. 9; „Nowy Dziennik” 1935, nr 10, s. 11, nr 15, s. 6.

54 F. Szopski, Z filharmonii. Oskar Fried, Bronisław Gimpel, „Kurier Warszawski” 1928, nr 291 (wydanie wieczorne), s. 10. ne), s. 5.

55 Bis. [L. Binental], Z sali filharmonii, „Kurier Warszawski” 1928, nr 27 (wydanie wieczor-

56 Idem, Z sali filharmonii, „Kurier Warszawski” 1930, nr 281 (wydanie wieczorne), s. 8.

57 Idem, Z koncertów, „Kurier Warszawski” 1931, nr 7 (wydanie wieczorne), s. 7. 
nił się ,wielką wybuchowością temperamentu urodzonego skrzypka”" ${ }^{\text {. }}$. W tym samym roku, przed przystąpieniem do konkursu skrzypcowego, Gimpel wystąpił w Krakowie. Recenzję z tego koncertu zamieścił krakowski syjonistyczny „Nowy Dziennik". Główny sprawozdawca tego pisma, Henryk Apte, który z wykształcenia był skrzypkiem, podzielił opinię innych krytyków na temat gry wirtuoza w wielu kwestiach. Za najistotniejsze walory jego gry uznał doskonałą technikę oraz piękny dźwięk - „liryczny, miękki, raczej kobiecy”. Zaliczając 24-letniego Gimpla do grona najwybitniejszych skrzypków „młodej generacji pochodzących z Polski”, miał jednak wątpliwości co do artystyczno-estetycznych aspektów jego interpretacji, zwłaszcza w odniesieniu do wirtuozowskiej brawury, zaburzającej miejscami równowagę jego skrzypcowych kreacji ${ }^{59}$.

Przytoczone opinie niektórych polskich recenzentów muzycznych (reprezentujących Warszawę, Lwów, Kraków i Łódź) na temat występów najwybitniejszych lwowskich skrzypków pochodzenia żydowskiego w okresie międzywojennym świadczą o sumienności i rzeczowości dziennikarzy. Ich recenzjom nie można odmówić rzetelnej informacji i wyważonej oceny. Biorąc pod uwagę opisane wcześniej wypowiedzi, można wyciągnąć wniosek, iż sprawozdawcy muzyczni zarówno polskich, jak i żydowskich czasopism pomijali aspekt przynależności etnicznej ocenianych przez nich artystów, koncentrując się wyłącznie na kwestiach wykonawczych. Nie oznacza to jednak, że dziennikarze (w tym recenzenci muzyczni) zupełnie pomijali kwestię przynależności narodowej żydowskich muzyków $^{60}$. Na przykład w serii doniesień prasowych dotyczących włoskiego tournée Gimpla w 1926 r., które zamieszczano w „Nowym Dzienniku”, często podkreślano narodowość żydowską skrzypka ${ }^{61}$. Ta swego rodzaju manifestacja była reakcją żydowskiej gazety na notkę opublikowaną w „Głosie Narodu” (krakowskim dzienniku reprezentującym poglądy klerykalne i antysemickie), w której zaakcentowano przynależność skrzypka do narodu polskiego ${ }^{62}$. Ciekawostką jest to, że chadecka gazeta dla uwiarygodnienia sensacyjnych wiadomości, anonsowanych już w tytule D'Annunzio wielbicielem polskiego dziecka, przedstawiła Gimpla jako 5-letnie „cudowne dziecko”, choć skrzypek miał wówczas 15 lat i był już młodzieńcem. Po-

58 Idem, Korespondencje. Międzynarodowy Konkurs Skrzypcowy im. Henryka Wieniawskiego, „Muzyka” 1935, nr 3-4, s. 79.

59 Dr. Apte [H. Apte], Z sali koncertowej. Bronistaw Gimpel, „Nowy Dziennik” 1935, nr 15, s. 5.

60 Do kwestii żydowskiej narodowości muzyków występujących w koncertach organizowanych przez krakowskie środowisko żydowskie odwoływał się nieraz sam Henryk Apte, wspomniany wcześniej sprawozdawca muzyczny „Nowego Dziennika”. Zob. K. Skwierczyński, Krytyka muzyczna na łamach żydowskiego „Nowego Dziennika” w latach 1918-1923, „Trubadur” 2004, nr 1.

${ }_{61}$ Pepin, Na marginesie. D'Annunzio i... „, Gtos Narodu” wielbicielami... żyd. dziecka, „Nowy Dziennik” 1926, nr 105, s. 4; 14-letni Bronisław Gimpel przyjęty przez króla włoskiego, „Nowy Dziennik” 1926, nr 245, s. 9; Bronisław Gimpel przyjęty przez papieża, „Nowy Dziennik” 1926, nr 280, s. 5.

${ }_{62}$ D'Annunzio wielbicielem polskiego dziecka, „Głos Narodu” 1926, nr 105, s. 2. 
nadto odniesienia do kwestii etnicznych pojawiały się w wydawanym w Warszawie dzienniku o nastawieniu syjonistycznym „Nasz Przegląd”. W krótkiej wzmiance o międzynarodowych sukcesach młodego Gimpla, zamieszczonej w rubryce $Z \dot{z} y c i a$ żydowskiego, znalazły się takie określenia, jak: ,znany wirtuoz żydowski”, „młody genialny skrzypek żydowski”, „na cześć utalentowanego muzyka żydowskiego"63.

Interesująco pod względem omawianej kwestii przedstawia się także artykuł o charakterze publicystycznym, poświęcony działalności koncertowej Gimpla, zamieszczony na łamach „Ilustrowanej Republiki” - łódzkiego dziennika przeznaczonego głównie dla spolonizowanej inteligencji żydowskiej. Autor tekstu, podpisany jako E. Bar, w swoim artykule uwypuklił polską narodowość skrzypka, pomijając przy tym informacje o jego żydowskich korzeniach, nawet przy okazji przywołania protoplasty rodu muzyków - Jakuba Bera Gimpla, założyciela sceny żydowskiej we Lwowie, pełniącej rolę ostoi kulturalnej języka jidysz w Galicji ${ }^{64}$. Zresztą prasa międzywojenna chętnie akcentowała polskie pochodzenie zarówno Gimpla, jak i Perutza i Eyle'a oraz ich związki ze Lwowem, szczególnie po wyjeździe artystów z kraju ${ }^{65}$.

Do wątku żydowskiego w odniesieniu do Gimpla nawiązywał Menachem Kipnis, śpiewak i zbieracz folkloru żydowskiego, w recenzji opublikowanej na łamach gazety „Hajnt”, wydawanej w języku jidysz w Warszawie. „Wylewna”, pełna ekspresji i subtelności uczuć gra Gimpla wzbudziła w nim wrażenia silne i nad wyraz głębokie. Przeżycia estetyczne Kipnisa były tak intensywne, że kunsztowi skrzypka przypisał niezwykle rzadką umiejętność operowania „tak bardzo szlachetną”, ,subtelną” i ,czarowną” barwą dźwięku, który ,jakby nosił w sobie dziedzictwo generacji, coś czym karmił się od dawna, czerpiąc ze źródeł przeszłości, od muzyków z pokolenia na pokolenie (muzyków żydowskich)" ${ }^{\prime 66}$. Opinia Kipnisa, odnosząca się do fenomenu gry Gimpla w kontekście wspólnego dziedzictwa kulturowego Żydów, z jednej strony eksponowała kwestię odmienności etnicznej jako swego rodzaju egzotykę o sile przyciągania mogącą zyskać uznanie, a z drugiej wpisywała się w ówczesne tendencje wypływające z przekonania o istnieniu ,niepowtarzalnych i niezmiennych historycznie cech ras ludzkich" (duchowych właściwości danej rasy), które mają wpływ na tożsamość artystyczną dzieła sztuki ${ }^{67}$.

63 Ż.A.T. [korespondencja z Wiednia], Bronisław Gimpel przybywa do Polski, „Nasz Przegląd" 1928, nr 16, s. 3.

${ }^{64}$ E. Bar, Artysta polski u Mussoliniego, „Ilustrowana Republika” 1932, nr 262, s. 8.

${ }^{65}$ „Wiadomości Krakowskie” 1922, nr 34, s. 7, nr 35, s. 6; jkb. [J. Kaden-Bandrowski], Z muzyki, „Świat” 1932, nr 17, s. 16; Rozmaitości, „Muzyk Wojskowy” 1928, nr 23, s. 9; Hallo! Tu radio, „Nowy Kurier” 1937, nr 214, s. 9.

66 Recenzja M. Kipnisa z koncertu B. Gimpla zamieszczona w dzienniku „Hajnt” z dnia 29 stycznia 1928 r. Cyt. za: I. Fater, op. cit., s. 101.

${ }_{67}$ Zob. A. Tuchowski, Nacjonalizm, szowinizm, rasizm a europejska refleksja o muzyce i twórczość kompozytorska okresu międzywojennego, Wrocław 2015, s. 34, 100. 
Wraz z postępem asymilacji społeczeństwa żydowskiego coraz więcej i antysemitów, i przedstawicieli społeczeństwa żydowskiego wskazywało na odrębność rasową (duchową) Żydów, podkreślając, że specyficzne cechy narodu żydowskiego są „niezbywalne” i pozostają w Żydach na zawsze. Antysemici akcentowali brak możliwości przystosowania się Żydów do innych społeczeństw, wzbudzając jednocześnie strach przed „obcością", natomiast strona żydowska w swych rozważaniach uwypuklała „wrodzone” cechy Żydów, wyróżniające ich spośród innych narodów ${ }^{68}$. W dyskusję na temat muzycznej kultury europejskiej z punktu widzenia różnicujących ją cech narodowych (rasowych) włączyli się również krytycy muzyczni, m.in. Zofia Lissa ${ }^{69}$ i Bronisława Wójcik-Keuprulian ${ }^{70}$, które odwoływały się do najnowszych badań antropologicznych Jana Czekanowskiego ${ }^{71}$, oraz Juliusz Adamski ${ }^{72}$, a także poruszający kwestię odrębności rasowej Żydów Józef Reiss $^{73}$ i Karol Szymanowski ${ }^{74}$.

Józef Reiss, znany polski muzykolog, prelegent i publicysta muzyczny, w rozprawie pt. Dusza żydostwa w muzyce, opublikowanej na łamach dwutygodnika „Muzyk Wojskowy”, odniósł się m.in. do słynnej rozprawy Ryszarda Wagnera Judentum in der Musik (1850) ${ }^{75}$. Reiss, w oparciu o ówczesne standardy badań naukowych z zakresu antropologii, udowadniał, że Żydzi są narodem niezwykle muzykalnym, a zdolności te zawdzięczają wielowiekowemu dziedzictwu. Jako że Żydzi są narodem wygnańców-tułaczy, rozproszonym „wśród obcych społeczeństw"76, nabyli wyjątkową elastyczność i łatwość w przystosowaniu się do nowych warunków. Ich „zdolność wczuwania się we wszystko, co obce”, w połączeniu z „niezwykłą subtelnością wrażliwości”, którą Reiss zinterpretował w oparciu o terminologię z zakresu psychologii jako „hiperestezję” (tj. nadwraż-

68 Zob. A. Landau-Czajka, op. cit., s. 68-73.

69 Z. Lissa, Problem rasy w muzyce, „Muzyka” 1934, nr 3, s. 108-112; eadem, Zagadnienia rasowe w muzyce, „Wiedza i Życie” 1937, z. 10, s. 657-665.

70 R. Eichenauer, Music und Rasse, J.F. Lehmanns Verlag, München 1932, rec.: B. WójcikKeuprulian, „Kwartalnik Muzyczny” 1933, nr 19-20, s. 172-176.

71 J. Czekanowski, Zarys antropologii, Lwów 1930.

72 J. Adamski, Czynnik rasowy i narodowościowy w muzyce, „Orkiestra” 1931, nr 8-9, s. 121123 , nr 10, s. 145-146, nr 11, s. 160-161, nr 12, s. 177-178; 1932, nr 1, s. 7-8, nr 2, s. 26-27, nr 3, s. 46-48, nr 4, s. 62-63, nr 5, s. 79-80, nr 8, s. 126-127.

73 J. Reiss, Dusza żydostwa w muzyce, „Muzyk Wojskowy” 1928, nr 9, s. 1-3, nr 10, s. 1-2, nr 11, s. 2-3, nr 13, s. 1-2, nr 14, s. 1-2.

${ }^{74}$ K. Szymanowski, Uwagi w sprawie wspótczesnej opinii muzycznej w Polsce, „Nowy Przegląd Literatury i Sztuki” 1920, t. 1, nr 2, s. 222. Problematyka żydostwa przyciągała uwagę Szymanowskiego, czego przykładem są pochodzące z początku 1922 r. jego rękopiśmienne zapisy, których fragmenty opublikowała Teresa Chylińska. Zob. idem, Kwestia żydowska, [w:] idem, Pisma, t. 2: Pisma literackie, zebrała i oprac. T. Chylińska, przedm. J. Błoński, Kraków 1989, s. 225-237.

75 M. Woźna-Stankiewicz, Muzykolog Józef Reiss - prelegent perfekcyjny, „Annales UMCS. Sectio L" 2013, nr 2, s. 71.

76 „Muzyk Wojskowy” 1928, nr 9, s. 1. 
liwość na bodźce) ${ }^{77}$, pozwoliły im nie tylko na „wchłonięcie zdobyczy zachodniej kultury muzycznej i wszystkich jej form”, ale także na przyswojenie „wszystkich najbardziej wyrafinowanych środków techniki muzycznej" ${ }^{\text {"78 }}$. Zdaniem Reissa Żydzi swe zdolności akomodacji wykazują nie tylko w dziedzinie twórczości muzycznej, ale również w dziedzinie wykonawstwa muzycznego, zwłaszcza jako pianiści, skrzypkowie, wiolonczeliści i dyrygenci. Poza tym są niedoścignionymi „mistrzami sztuki odtwórczej”, ponieważ tworzą „idealną interpretację kompozycji” dzięki zdolności „zatopienia się w niej i przeżycia jej treści nastrojowej w takim stopniu, w jakim nie posiada tej zdolności nikt inny" ${ }^{\prime 79}$. W tym miejscu Reiss zgadzał się z opinią Karola Szymanowskiego, który w 1920 r. na łamach polskiej prasy wyraził opinię na temat dużej muzykalności Żydów, którą uznał raczej za przejaw „łatwości gestu” (tj. zdolności w nabywaniu umiejętności) niż „twórczego instynktu” ${ }^{\prime \prime}$.

Wracając do kwestii muzycznego środowiska międzywojennego Lwowa, trzeba podkreślić, że - w przeciwieństwie do społeczności ukraińskiej, która wykazywała bardziej tendencje do zamknięcia się w swoim gronie - muzycy pochodzenia żydowskiego tworzyli z Polakami jedno integralne środowisko ${ }^{81}$. Mimo to sporadycznie dochodziło w nim do pewnych konfliktów, wynikających z odmiennych religijno-kulturowych tradycji Żydów i Polaków. Jak wynika z doniesień prasowych, we wrześniu 1925 r. liczni członkowie orkiestry operowej narodowości żydowskiej odmówili występu w dniu, w którym przypadało Jom Kipur (Sądny Dzień lub Dzień Pojednania), czyli jedno z najważniejszych świąt żydowskich, obchodzone nawet przez całkowicie zasymilowanych, niewierzących Żydów, którzy ten jeden dzień w roku traktowali jako obyczaj, swego rodzaju symbol łączący ich ze społeczeństwem żydowskim ${ }^{82}$. W związku z zapowiedzianą absencją muzyków premiera opery Faust Charles'a Gounoda, przewidziana na 27 września, została przez dyrekcję Teatru Wielkiego przesunięta o dwa dni ${ }^{83}$. W przypadającym po święcie żydowskim w dniu 29 września okrzyki antysemickie i gwizdy wśród publiczności zebranej w Teatrze Wielkim poprzedziły podniesienie kurtyny rozpoczynające premierę opery Faust Gounoda. Demonstracje antyżydowskie przeniosły się dnia następnego kolejno przed budynek redakcji „Chwili” i gmach Teatru Wielkiego ${ }^{84}$.

77 „Muzyk Wojskowy” 1928, nr 13, s. 1.

78 „Muzyk Wojskowy” 1928, nr 11, s. 2-3.

79 „Muzyk Wojskowy” 1928, nr 13, s. 1.

${ }^{80}$ K. Szymanowski, Uwagi w sprawie współczesnej opinii..., s. 222.

81 Zob. skład grona pedagogicznego w Wyższym Muzycznym Instytucie im. M. Łysenki we Lwowie w: L. Mazepa, T. Mazepa, op. cit., s. 252-254.

82 A. Landau-Czajka, op. cit., s. 273-274.

83 Demonstracja w Teatrze Wielk., „Gazeta Lwowska” 1925, nr 225, s. 2.

${ }^{84}$ Sądny dzień w teatrach lwowskich, „Słowo Polskie” 1925, nr 265, s. 8; Demonstracja w Teatrze Wielk., „Gazeta Lwowska” 1925, nr 225, s. 2; Wichrzyciele przy pracy. Wybryki antysemickie w Teatrze Wielkim, „Chwila” 1925, nr 2348, s. 6; Demonstracje antyżydowskie we Lwowie, „Kurier 
Trzeba zaznaczyć, że opisane wydarzenia były udziałem jedynie wąskiej grupy mieszkańców Lwowa, niezwiązanych ze środowiskiem muzycznym. Wyrazicielem nastrojów panujących wśród lwowskich muzyków był pianista i kompozytor Witold Friemann, który w recenzji prasowej z premiery Fausta w odniesieniu do zajść w teatrze zamieścił jedynie skąpą informację: ,,[...] krzyki i wrzawa na galerii [...] skierowane przeciwko licznym niepolskim elementom w orkiestrze"85.

Z kolei ostry sprzeciw ze strony czołowych działaczy społecznych i organizatorów amatorskiego ruchu śpiewaczego z terenu województw: lwowskiego, stanisławowskiego i tarnopolskiego (wśród nich byli także muzycy o korzeniach żydowskich, np. Wiktor Hausman) ${ }^{86}$, skupionych wokół Małopolskiego Związku Polskich Towarzystw Śpiewaczych i Muzycznych, wywołał koncert orkiestry Filharmonii Lwowskiej pod dyrekcją Jakuba Munda - koncertmistrza i skrzypka żydowskiego pochodzenia, który odbył się w marcu 1937 r. w Niedzielę Palmową, a więc w dniu rozpoczynającym według tradycji katolickiej Wielki Tydzień. Powodem protestu był program koncertu, w którym zamiast muzyki o tematyce pasyjnej rozbrzmiewała muzyka taneczna ${ }^{87}$.

Asymilujący się Żydzi w okresie międzywojennym byli narażeni na ataki obu stron: tradycyjnej polskiej i tradycyjnej żydowskiej. Największa niechęć antysemitów była skierowana przeciwko Żydom zasymilowanym, spolonizowanym, a nawet przeciw Polakom pochodzenia żydowskiego, którzy w ich opinii usiłowali przeniknąć do społeczeństwa polskiego jako ci, którzy tylko imitują swoje przywiązanie do kraju. Co więcej, także Żydzi, którzy przyjęli wyznanie rzymskokatolickie, byli traktowani przez dużą część polskiej społeczności jako obcy, a z kolei przez środowiska żydowskie byli wyrzucani poza nawias tej społeczności ${ }^{88}$. Charakterystyczny dla większości zasymilowanych Żydów był zatem dylemat tożsamości, swoisty stan zawieszenia pomiędzy dwiema kulturami. W kwestii „swojej podwójnej identyfikacji narodowej”"89 wypowiedział się w międzywojniu Bronisław Huberman, polski skrzypek-wirtuoz żydowskiego pochodzenia, jeden z najwybitniejszych polskich skrzypków pierwszej połowy XX w.,

Lwowski” 1925, nr 230, s. 5; Echa „sądnego dnia” we Lwowie, „Głos Lubelski” 1925, nr 271, s. 2-3. Incydenty antyżydowskie związane z obchodzonym przez Żydów świętem Jom Kipur miały miejsce również w Warszawie w dniach 28-29 września 1925 r. Zob. Jom Kipur, „Nowy Dziennik” 1925, nr 221, s. 4.

85 W. Friemann, ,Faust” Gounoda, „Słowo Polskie” 1925, nr 271, s. 5.

86 Wiktor Hausman (1892-1943) - kompozytor i dyrygent, profesor Konserwatorium Polskiego Towarzystwa Muzycznego we Lwowie, od 1937 r. dyrektor Konserwatorium Towarzystwa Muzycznego im. Stanisława Moniuszki w Stanisławowie.

87 J.J. Dunicz, Z ruchu muzycznego ..., „Muzyka Polska” 1937, z. 5, s. 250; Wiadomości bieżace, „Gazeta Lwowska” 1937, nr 63, s. 2; Zjazd Delegatów Polsk. Towarzystw Śpiewaczych i Muzycznych, „Gazeta Lwowska” 1937, nr 68, s. 2.

88 W. Wierzbieniec, op. cit., s. 33-34, 43; A. Landau-Czajka, op. cit., s. 23-24, 41, 54-55.

89 A. Landau-Czajka, op. cit., s. 23. 
z którym Gimpel był porównywany ${ }^{90}$. Huberman, z punktu widzenia artysty, uważał ową fuzję obu kultur za atut nadający pewien koloryt jego interpretacjom, stanowiący swego rodzaju znak rozpoznawczy jego sztuki wykonawczej, za co został uznany w Szwecji za „ucieleśnienie słowiańskiego patosu i mistyki Semity"'91. Genialny skrzypek w jednym z wywiadów dla polskiej prasy powiedział:

W rzeczywistości przecież ta cała historia hitleryzmu i rasowości jest bezdennie głupia i zupełnie niepoważna. Twórczość, jak zresztą każda inna działalność ducha ludzkiego, jest pełna niezbadanych tajemnic. To jak gdyby misterium. Procesy twórczości są na wskroś indywidualne i nie można ich generalizować ani pod względem rasowym, ani wyznaniowym. Wielką rolę w procesie twórczym odgrywają tego rodzaju momenty, jak wpływ otoczenia, wrażenia z okresu dzieciństwa, przeżycia. Tak jak gram, może grać jedynie Żyd polski. Nie mógłby natomiast tak grać nigdy Żyd niemiecki, choćby był największym nawet wirtuozem ${ }^{92}$.

Wielu lwowskich muzyków pochodzenia żydowskiego (w tym wielu skrzypków) zginęło podczas wojny. W obozie zagłady przy ul. Janowskiej we Lwowie śmierć ponieśli m.in. Marek Bauer, Marceli Horowitz, Jakub Mund, Dawid Deutsch, Zygmunt Schatz, Leopold Striks, Leon Sak ${ }^{93}$. W zorganizowanej latem 1942 r. orkiestrze obozowej grali J. Mund, L. Striks oraz Z. Schatz, który był twórcą tanga śmierci granego podczas odprowadzania grupy więźniów na Piaski (teren poza obozem, gdzie dokonywano egzekucji ${ }^{94}$. W czasie wojny nastąpił także tragiczny koniec lwowskiej rodziny Gimplów związanej z żydowskim teatrem we Lwowie. Rodzice Bronisława Gimpla zginęli w obozie zagłady w Bełżcu, a jego brat Karol, pianista, z którym często współpracował - w więziennym szpitalu w Bucharze.

90 Zob. I. Fater, op. cit., s. 101.

91 Cyt. za: P. Szalsza, Bronisław Huberman, czyli pasje i namiętności zapomnianego geniusza. Monografia muzyczna skrzypka-wirtuoza, Częstochowa 2001, s. 158.

92 Wywiad z Bronisławem Hubermanem opublikowany na łamach „Naszego Przeglądu”, 6.05.1933. Cyt. za: P. Szalsza, op. cit., s. 186.

93 M. Gołąb, Józef Koffler, Kraków 1995, s. 236; L.T. Błaszczyk, op. cit., s. 26, 55, 81, 113, 217, 219, 235; M.M. Borwicz, op. cit., s. 235.

94 M.M. Borwicz, op. cit., s. 229. 


\section{BIBLIOGRAFIA}

\section{Źródla}

14-letni Bronisław Gimpel przyjęty przez króla włoskiego, „Nowy Dziennik” 1926, nr 245.

Alf.[red] Jen.[dl], Z muzycznej estrady i sceny, „Wiadomości Krakowskie” 1922, nr 41.

Bar E., Artysta polski u Mussoliniego, „Ilustrowana Republika” 1932, nr 262.

Bis. [L. Binental], Korespondencje. Międzynarodowy Konkurs Skrzypcowy im. Henryka Wieniawskiego, „Muzyka” 1935, nr 3-4.

Bis. [L. Binental], Z koncertów, „Kurier Warszawski” 1931, nr 7 (wydanie wieczorne).

Bis. [L. Binental], Z sali filharmonii, „Kurier Warszawski” 1928, nr 27 (wydanie wieczorne).

Bis. [L. Binental], Z sali filharmonii, „Kurier Warszawski” 1930, nr 281 (wydanie wieczorne).

Bronisław Gimpel przyjęty przez papieża, „Nowy Dziennik” 1926, nr 280.

Cofalik A., Ukochałem skrzypce. Ze wspomnień skrzypka i pedagoga, Kraków 2016.

D’Annunzio wielbicielem polskiego dziecka, „Głos Narodu” 1926, nr 105.

Demonstracja w Teatrze Wielk., „Gazeta Lwowska” 1925, nr 225.

Demonstracje antyżdowskie we Lwowie, „Kurier Lwowski” 1925, nr 230.

Dr. Apte [H. Apte], Z sali koncertowej. Bronisław Gimpel, „Nowy Dziennik” 1935, nr 15.

Dunicz J.J., Z ruchu muzycznego w Polsce. Lwów, „Muzyka Polska” 1936, z. 2.

Dunicz J.J., Z ruchu muzycznego ..., „Muzyka Polska” 1937, z. 1.

Dunicz J.J., Z ruchu muzycznego ..., „Muzyka Polska” 1937, z. 5.

Echa ,sądnego dnia” we Lwowie, „Głos Lubelski” 1925, nr 271.

Friemann W., ,Faust” Gounoda, „Słowo Polskie” 1925, nr 271.

„Gazeta Lwowska” 1929, nr 1; 1932, nr 226.

Hal F.R., Teatr i muzyka, „Głos Polski. Dziennik polityczny, społeczny i literacki” 1924, nr 17.

Hallo! Tu radio, „Nowy Kurier” 1937, nr 214.

„Ilustrowana Republika” 1928, nr 39-40.

jkb. [J. Kaden-Bandrowski], Z muzyki, „Świat” 1932, nr 17.

Jom Kipur, „Nowy Dziennik” 1925, nr 221.

K.[arol] S.[tromenger], Robert Perutz. (Wspomnienie pośmiertne), „Gazeta Polska” 1934, nr 86.

Koncert skrzypka wirtuoza, „Goniec Częstochowski” 1919, nr 43.

Koncerty. Uczniowski koncert Konserwatorium P.T.M., „Echo. Miesięcznik poświęcony kulturze muzycznej Lwowa" 1936, nr 2.

Kronika, „Gazeta Narodowa” 1898, nr 191.

Łobaczewska S., Z sali koncertowej. J. Alter, „Gazeta Lwowska” 1928, nr 294.

Mitscha A., Z sali koncertowej. Feliks Eyle, „, Słowo Polskie” 1922, nr 5.

„Nasz Przegląd” 1928, nr 288.

Neuhauser F., Z muzyki, „Gazeta Lwowska” 1919, nr 134.

Niewiadomski S., Przegląd muzyczny, „Słowo Polskie” 1904, nr 559.

„Nowy Dziennik” 1928, nr 13, 350; 1932, nr 257, 266; 1935, nr 10.

Pepin, Na marginesie. D’Annunzio i... „, Gtos Narodu” wielbicielami... żyd. dziecka, „Nowy Dziennik" 1926, nr 105. 
Perutz R., Wrażenia z Koncertu Paderewskiego w Ameryce, „Muzyka” 1931, nr 3.

Plohn A., Z sali koncertowej. Feliks Eyle, „Chwila” 1922, nr 1337.

„Polska Zachodnia” 1935, nr 5-6, 12.

Rozmaitości, „Muzyk Wojskowy” 1928, nr 23.

S.[tromenger] K., Robert Perutz (Wspomnienie pośmiertne), „Gazeta Polska” 1934, nr 86.

Sąny dzień w teatrach lwowskich, „Słowo Polskie” 1925, nr 265.

„Słowo Polskie” 1922, nr 207.

st.[anisław] n.[iewiadomski], Z sali koncertowej, „Gazeta Muzyczna” 1919, nr 19/20.

Stromenger K., Przeglad muzyczny, „Tygodnik Ilustrowany” 1927, nr 39.

Szopski F., Z filharmonii. Oskar Fried, Bronisław Gimpel, „Kurier Warszawski” 1928, nr 291 (wydanie wieczorne).

Walter E., Z muzyki. (Koncert Roberta Perutza), „Gazeta Lwowska” 1913, nr 87.

Wiadomości bieżace, „Gazeta Lwowska” 1937, nr 63.

„Wiadomości Krakowskie” 1922, nr 34-35.

Wiadomości z kraju i z zagranicy, „Gazeta Muzyczna” 1919, nr 11, 24.

Wichrzyciele przy pracy. Wybryki antysemickie w Teatrze Wielkim, „Chwila” 1925, nr 2348.

„Zakopane” 1930, nr 30-31.

Zjazd Delegatów Polsk. Towarzystw Śpiewaczych i Muzycznych, „Gazeta Lwowska” 1937, nr 68.

Ż.A.T. [korespondencja z Wiednia], Bronisław Gimpel przybywa do Polski, „Nasz Przegląd” 1928, nr 16.

\section{Literatura}

Adamski J., Czynnik rasowy i narodowościowy w muzyce, „Orkiestra” 1931, nr 8-9, 10, 11, 12; 1932, $\mathrm{nr} 1,2,3,4,5,8$.

Błaszczyk L.T., Żydzi w kulturze muzycznej ziem polskich w XIX i XX wieku. Słownik biograficzny, Warszawa 2014.

Borwicz M.M., Uniwersytet zbirów. Rzecz o Obozie Janowskim we Lwowie 1941-1944, Kraków 2014.

Czekanowska A., Muzyka żydowska - modlitwa i pieśń, [w:] eadem, Kultury tradycyjne wobec współczesności. Muzyka, poezja, taniec, Warszawa 2008.

Czekanowski J., Zarys antropologii, Lwów 1930.

Dahlig P., O Jankiel - historia, poezja i codzienność, „Muzykalia” 2012, z. 13/Judaica 4.

Fater I., Bronisław Gimpel (1911-1979), [w:] idem, Muzyka żydowska w Polsce w okresie międzywojennym, Warszawa 1997.

Fuks M., Muzyka ocalona. Judaica polskie, Warszawa 1989.

Fink K., Szkolnictwo muzyczne we Lwowie w okresie międzywojennym, „Molod' ̀̀ rinok. Somìsâčnij naukovo-pedagogìnnij žurnal” 2017, nr 4.

Fuks M., Tradycje muzyczne polskich Żydów, [w:] Studia z dziejów Żydów w Polsce. Materiały edukacyjne dla szkót średnich $i$ wyższych, red. E. Lewczuk, t. 2, Warszawa 1995.

Fuks M., Wielcy i sławni pochodzenia żydowskiego, Łódź 1998.

Gawroński L., Saga rodu Wieniawskich, Lublin 2003. 
Gołąb M., Józef Koffler, Kraków 1995.

Jakubczyk S., Klezmerskiej muzyki próba zrozumienia retrospektywna, „Kwartalnik Młodych Muzykologów UJ" 2008, nr 2.

Jakubczyk-Ślęczka S., Żydowskie środowisko muzyczne międzywojennego Lwowa, „Musica Galiciana" 2014, t. 14.

Kotula F., Muzykanty, Warszawa 1979.

Landau-Czajka A., Syn będzie Lech... Asymilacja Żydów w Polsce międzywojennej, Warszawa 2006.

Lissa Z., Problem rasy w muzyce, „Muzyka” 1934, nr 3.

Lissa Z., Zagadnienia rasowe w muzyce, „Wiedza i Życie” 1937, z. 10.

Mazepa L., Mazepa T., Šláh do Muzičnoi Akademii u L'vovi, t. 1, L'viv 2003.

Mazur G., Życie polityczne polskiego Lwowa 1918-1939, Kraków 2007.

Menuhin Y., Skrzypce i ja, przy współudziale C. Meyer, Warszawa 2000.

Nowicka E., Swojskość i obcość jako kategorie socjologicznej analizy, [w:] Swoi i obcy, red. E. Nowicka, Warszawa 1990.

Palmon H., Żydowskie środowisko muzyczne Lwowa między wojnami światowymi, www.demusica. pl/cmsimple/images/file/dm13_palmon.pdf [dostęp: 15.09.2017].

Piekarski M., Przerwany kontrapunkt. Adolf Chybiński i początki polskiej muzykologii we Lwowie 1912-1944, Warszawa 2017.

Plohn A., Muzyka we Lwowie a Żydzi, „Muzykalia” 2012, z. 13/Judaica 4.

R. Eichenauer, Music und Rasse, J.F. Lehmanns Verlag, München 1932, rec.: B. Wójcik-Keuprulian, „Kwartalnik Muzyczny” 1933, nr 19-20.

Reiss J., Dusza żydostwa w muzyce, „Muzyk Wojskowy” 1928, nr 9-11, 13-14.

Simmel G., Obcy, [w:] idem, Socjologia, Warszawa 1975.

Skwierczyński K., Krytyka muzyczna na łamach żydowskiego „,Nowego Dziennika” w latach 19181923, „Trubadur” 2004, nr 1.

Szalsza P., Bronisław Huberman, czyli pasje i namiętności zapomnianego geniusza. Monografia muzyczna skrzypka-wirtuoza, Częstochowa 2001.

Szymanowski K., Kwestia żydowska, [w:] idem, Pisma, t. 2: Pisma literackie, zebrała i oprac. T. Chylińska, przedm. J. Błoński, Kraków 1989.

Szymanowski K., Uwagi w sprawie współczesnej opinii muzycznej w Polsce, „Nowy Przegląd Literatury i Sztuki" 1920, t. 1, nr 2.

Tuchowski A., Nacjonalizm, szowinizm, rasizm a europejska refleksja o muzyce i twórczość kompozytorska okresu międzywojennego, Wrocław 2015.

Vogel B., „Na wierzbach zawiesiliśmy nasze... skrzypce”. Rzecz o dawnych instrumentach, macewach, synagogach i klezmerach, „Muzyka” 2007, nr 2.

Weber J., Gimpel Bronisław, [w:] Encyklopedia muzyczna PWM. Część biograficzna, red. E. Dziębowska, t. 3, Kraków 1987.

Wierzbieniec W., Żydzi w województwie lwowskim w okresie międzywojennym. Zagadnienia demograficzne i społeczne, Rzeszów 2003.

Woźna-Stankiewicz M., Muzykolog Józef Reiss - prelegent perfekcyjny, „Annales UMCS. Sectio L” 2013, nr 2. 
„Znak od Boga”. Z Ida Haendel, światowej sławy skrzypaczka, jurorem XIII Konkursu Skrzypcowego im. H. Wieniawskiego, rozmawia Agnieszka Lewandowska, „Twoja Muza” 2007, nr 1.

\section{SUMMARY}

There were many great violinists of Jewish descent in interwar Lviv. They participated in Polish musical life as soloists, chamber musicians, conductors, members of orchestras and teachers. Along with creating their local music scene, they performed on various Polish and foreign stages and played for Polish Radio. Among the most talented Jewish violin virtuosos connected with Lviv at that time were Robert Perutz, Feliks Eyle and Bronisław Gimpel. The subject contained in this study's title refers to music critics' ("elite") approach to Lviv musicians of Jewish descent ("outsiders") in the interwar period, i.e. the period of manifesting antisemitism and nationalism.

Keywords: Lviv; Second Polish Republic; Jews; violinists; music critique 